\title{
Another Look at the Political Economy of the Mainstream and New Media: The Capitalists Influence
}

\section{Apuke OD*}

Department of Mass Communication, Taraba State University, Jalingo, Nigeria

\begin{abstract}
This paper examined the political economy of the mainstream and new media, it explicates how media industry, the political economy of the media and capitalism affects the accessibility of information in the new media. The study established that the political economy of the media deals with the generation and distribution of resources (film, social media, online newspapers etc) and that power (capitalism) affects it. The paper's design method is a narrative literature review and the data sources included Google scholar, blogs, Google, and the web of science. Books, print journals, magazines, were also used. A narrative review was conducted between March and May 2017. The paper outlined and discussed the issues raised, into themes concerning political economy of the media; new media; Marxist and Pluralist view of media ownership; the political economy of the new media and the influence of capitalism on the accessibility of information from the new media. The study revealed that capitalism is one of the driven forces that affects the pluralism and democratization of information on the internet; due to capitalism some classified information are sold and copyrighted.
\end{abstract}

Keywords: New media; Capitalism; Political economy; Pluralism; Democratization; Information

\section{Introduction and Background to the Study}

This paper begins with the conceptual definition of information communication technology, new media, cultural industry, and political economy of the media. It also examines the Marxists and Pluralist view of media ownership and control as well as the effect of the media industry, cultural industry and political economy of the media on new media's accessibility of information. Apuke [1] describes the information and communication technologies as communication gadgets, hardware, equipment or facilities that have modernized, improve and ease the exchange of ideas and information of various kinds between people within or across distant boundaries or frontiers. On the other hand, new media could also be described as an interactive and user feedback media that improves creative participation. Most common is websites such as blogs, wikis, video games and social media. A pool of literature concords to the fact that the new media major characteristics are dialogue, it transmits information, of ideas, emotions, written speech and other documented knowledge through connection and conversation. Through new media, people share and receive various information across the globe. This implies that the advent of new media technology has enabled democratization, pluralism and universal access to technological contents by people today as supported by many kinds of literature. However, going by the concept of democracy, and democratic participant media theory, media content is said to be generated from the people, by the people and for the people and pluralism implies information access by anyone in respective of gender, race, and occupation. Supporting this notion, Folarin [2], avers that democratic participant theory discards the top down communication system that involves professionals and commercial driven motive operators who hijack the media for their selfish interest but agitate for pluralize and democratize form of access and production of media contents. The theory advocates that media content generation, production, and dissemination should be done by one person to another instead of concentrating on particular top groups. It calls for the media to be a medium of the people, for the people and by the people rather than a medium in the hands of a few monopolistic groups. Buttressing on this point, Okunna [3] avers that "there is in this theory a desire for more horizontal rather than vertical (top-down) communication." And it is believed that this theory is highly applicable to the new media information production and retrieval, where people are opportune to be both content generators and retrievers. Against this axiom, this study examines the extent at which the new media content is readily accessible, as well as factors that affect the universal access and democratization of information in the new media. Therefore, the essay explores the assertion in "the world today the diversity of new communication technologies and new media, the democratization of communication, and the universal access to technological content are nothing than a myth. It reveals whether the easy access to information and democratization of information and diversity of new communication is just a myth or not as far as culture industry, media industry, and political economy of the media is concerned. In order to understand the myth or no myth involve in the new media as regards to the above, it is necessary to start this argumentative essay by explicating the concept of the culture industry, media industry, political economy of the media, and then examine the political economy of the new media, exploring the effect of capitalism on the new media and explicate if all these affects the pluralism and access to information in the new media. To better understand the hub of this study (Figure 1), below captures the themes to be covered in this study.

\section{Methodology}

A narrative review of the literature was conducted from March to May of 2017. The researcher searched the following database sources: Google scholar, Google, and the web of science. At the initial search,

*Corresponding author: Apuke OD, Department of Mass Communication, Taraba State University, Jalingo, Nigeria, Tel: 07037570917; E-mail: apukedestiny@gmail.com

Received June 23, 2017; Accepted July 06, 2017; Published July 10, 2017

Citation: Apuke OD (2017) Another Look at the Political Economy of the Mainstream and New Media: The Capitalists Influence. J Mass Communicat Journalism 7: 341. doi: 10.4172/2165-7912.1000341

Copyright: ( 2017 Apuke OD. This is an open-access article distributed under the terms of the Creative Commons Attribution License, which permits unrestricted use, distribution, and reproduction in any medium, provided the original author and source are credited. 


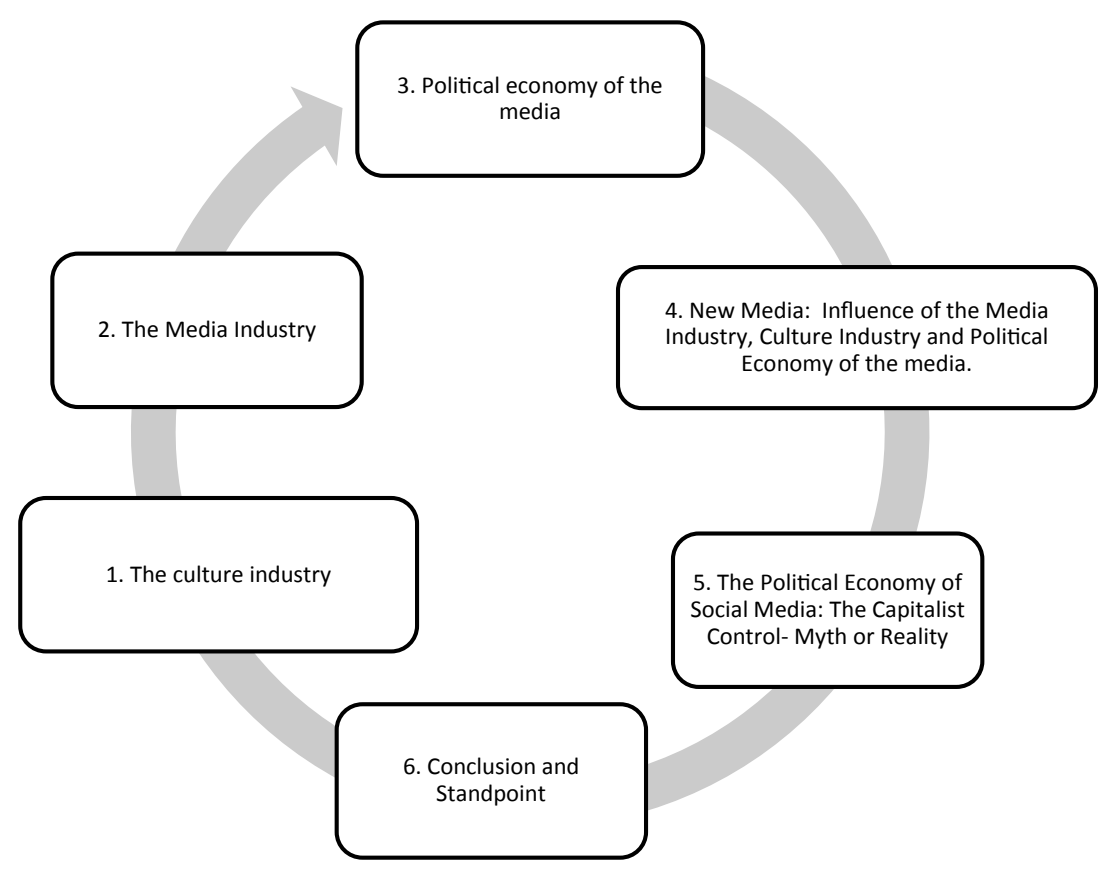

Figure 1: Study Structure and themes that form the literature.

results yielded about 560 references, which is related to the work on a closer look, but 67 was found more related and used for this narrative review. The main reason for using the included references was that it was more related and relevant to the subject matter. Another reference list of relevant sources included books, magazine, and print academic journals. Article publication date ranges from 1988 to 2016. Search words and phrases included culture industry, media industry, and the political economy of the media, functions of the media, media ownership and control.

\section{The Culture Industry}

In understanding the cultural industry, it is pertinent to define culture and examine popular and mass culture. Therefore, culture is the way of life/beliefs of a group of people leaving in a geographical location who are bound by language and as well values, behaviors, and attitudes. Kellner [4] see culture in today's societies "as comprising of a set of discourses, stories, images, spectacles, and varying cultural forms and practices that generate meaning, identities, and political effects and these include artifacts such as newspapers, television programs, movies, and popular music, but also practices like shopping, watching sports events, going to a club, or hanging out in the local coffee shop".

More so, culture could be popular or mass, popular cultures are those cultures that gradually sprout out in a given society; it starts gradually and then spreads between people. Popular culture normally starts from a given point, and then eventually gets recognition and popularity. Storey [5] see it as a culture "well-liked and favored by many." For example, when iPhones were launched it was only known by few people but as time goes on it started getting recognition and people started embracing it. Therefore, popular culture is a culture or practice that becomes well known and is embraced by the people. Another instance of popular culture is the use of Jean-trousers that was initially by railway workers, but eventually, people started using it and it became popular and well known. West (ND) describes popular culture as ubiquitous, something we come across on the internet, music, television, games or movies, and the most common are slangs, music's, dances, fashion as well as technological devices.

It should be noted that popular culture spreads by the means of mass media, thereby transforming popular culture into mass culture i.e., culture practiced by many people. Therefore, mass culture refers to a culture that is widely spread through the mainstream media, while in today's society, platforms such as Facebook, Twitter, National radio and National television also contribute in the distribution of culture. This means that the mass media make a popular culture to be mass. By so doing, culture is common and also a well-known part of everyday life of a person or a group of people, thus, special cultural products are remarkable, assisting people to view and comprehend things they've never quite come to realize or understand like certain films or novels that change ones view of the world.

However, going by the culture industry's ideology, scholars believed that popular culture has been turned or transformed into a factory that produces standard cultural goods such as films, radio programmes, and magazines with the aim of turning people into accepting whatever they see i.e., making them passive instead of active participants. Buttressing on this, Horkheimer et al. [6], remark that culture industry is likened to a processing plant that delivers institutionalized social merchandise, they contend that movies, radio projects, magazines, and so forth are used to control mass society into passivity. Similarly, Grant, (ND) postulates that "culture industry concept is a thesis proposed by Adorno and Horkheimer of the Frankfurt school, they contend that cultural industries exist to enforce (and reinforce) the capitalist ethos". They came up with a good approach to cultural and communications studies by combining a critique of political economy of the media, analysis of texts, and audience reception studies of the social and ideological effects of mass culture and communications. The term culture industry was coined to mean the process of industrializing mass-produced culture in which the commodities of the culture industries exhibited the same features as other products of mass production: commodification, 
standardization, and massification. In addition, Kellner [7], avers that the culture industries had the specific function, however, of providing ideological legitimation of the existing capitalist societies and of integrating individuals into the framework of the capitalist system. In the same manner, Fisher [8], revealed that the main argument of the culture industry is that the commodification of culture is the commodification of human consciousness. Adorno and Horkheimer assert that the culture industry eradicates autonomous thinking and criticism, serving to preserve the reigning order. It provides easy entertainment which distracts the masses from the wrongs and sickness of the ruling order. The main focus of the Frankfurt school was about culture and technology, revealing how technology started becoming both a basic force of production and the formative mode of social organization as well as control. Therefore, in accordance with Fisher's submission, Grant, (ND) encapsulates the key claims of the thesis as: the more difficult something is to reproduce, the more it is fetishized and sustained, as culture is used by capitalism to control the individual consciousness, so too does it become "industrialized" and commodified, where art was once also a commodity, in a capitalism it is to all extents a commodity and is often successful through the evocation and manipulation of desires.

Therefore, the culture industry has taken the people's view of reality, totally shaping and conditioning their experience of life. They keep the workers busy; brainwashing into believing whatever that is projected in the media as the reality of life. However, discussing the adverse effects of the culture industry, Fisher [8], remarks that Adorno and Horkheimer proposed that the culture industry positions the masses as objects of manipulation (instead of just satisfying their wants and needs) it turns people into passive and subordinated subjects, unable to fully take critical responsibility for their own action, a thing which is crucial to a functioning democracy. People therefore gladly give in a help to maintain the system by taking part in it. The Culture Industry was, therefore, a direct extension of the new industries of mass reproduction and distribution which had begun at the turn of the 19thcentury film, sound recording, mass circulation dailies, popular prints and later, radio broadcasting [9]. Furthermore, the Culture Industry found its full purpose when it became integrated into the new system of monopoly capitalism, which was predicated on total control of the masses. Here Adorno equates the American culture industry with European fascism [9].

In like manner, the Frankfurt school theorists argued that the media were controlled by groups who employed them to further their own interests and power [4]. Thus, in today's new media age, the culture industry and the capitalist society still thrive, in the sense that the masses are being made to want what technology can offer them. Through adverts, pay TV, subscription for internet access, the masses keep enriching the capitalist society. The new media are controlled by groups who employ them to further their interest and power. The capitalist society produced and distributes culture through the new media making us more passive than active. For instance, we have latest dance steps, clothes, and way of talking (slangs). All these are fostered through the media industry in the form of new media; the internet, and Pay TVs etc.

\section{Media Industry}

As mentioned above, this study will also examine the media industry. The media industry manufactures/produces, packages, process and distribute entertainment and other information contents through books, newspapers, recorded music's and motion pictures, Television and radio programming as well as internet/new media.
The media industry is therefore integrated into all the spheres of the society, ranging from economy, politics, and culture. The media shape our thinking of reality; it helps in forging one's identity as well as the notion of being male or female. More so, the media projects to us what class, ethnicity, race, and nationality is all about. The media, therefore, are likened to a mirror through which we see reality. Buttressing on this, Kellner [4], submits that the "media industries are powerful forces in contemporary societies, and it is essential to comprehend how they work in order to understand, act on, and transform the environment in which we live our lives. In the same way, the media industries produce entertainment and news and information, they are commercial enterprises and thrive on advertising, thus helping to reproduce a media and consumer society". In addition, the media industry is said to be a medium/platform for political leaders who use it for electioneering campaign as well as witch hunting of political opponent, it is, therefore, a basic machinery employed by political leaders who transform it into an arena upon which political battles are fought and manipulation and dominations are achieved. On the other hand, the media take control of social life, the media dominate many people's leisure activities and help construct how many people see the world and insert themselves in the established society. The media influence people's ideas, beliefs, and actions, it is monological in nature in the sense that it reaches mass audiences, hypnotize and manipulate them into being dominated by the ruling class. Just as the Marxist opined, the media have been a tool in the hands of the rich used to manipulate the working class into passivity (Figure 2).

Through the media industry, mass culture's distribution is achieved and as people keep watching and using technological devices they are hypnotized into mass culture unknowingly. They tend to be "Obedient servants" as shown in Figure 1. Nevertheless, it is vital to also examine the political economy of the media in order to get a better grasp of the media industry. What then is the relationship between the media industry and the cultural industry?

\section{Political Economy of the Media}

"Political economy is a branch of social science that studies the relationships between individuals and society and between markets and the state, using a diverse set of tools and method drawn largely from economics, political science, and sociology" [9]. Furthermore, political economy "involves the idea of media ownership, the media market, and financial support. Remarks that in the capitalist societies the capitalized and commercialized mass media have little difference from the other commodities in nature, they resemble the other commodities very much, both are used for profit for the capitalists, and are bound to be heavily dependent on the capitalist because their

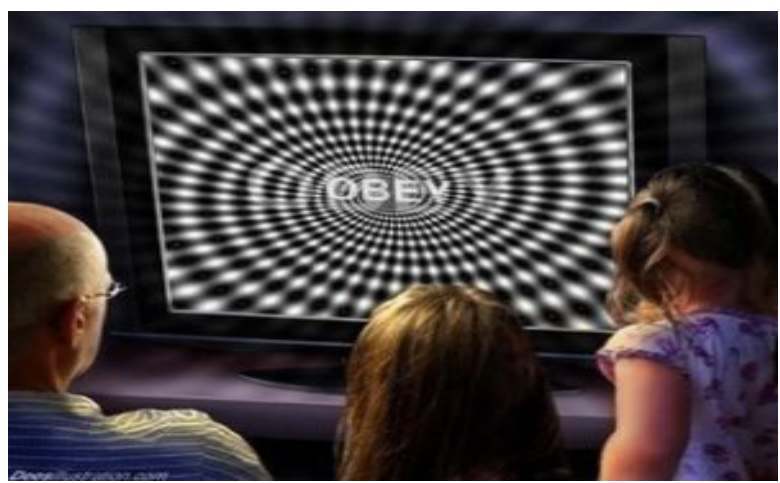

Figure 2: The hypnotizing effect of the Media Industry. 
operations are ensured by the sponsorship from the enterprises and advertising revenues. This cripples the independence of mass media, thereby making it an illusion. Buttressing on this [10-12], assert that the manner in which the media operate is shaped by their owners, the market environment, and the financial support (from the capitalist). In this environment, the media manufactures cultural content that sustains the system 'capitalism.' The media are therefore in the business of maximizing profits just like any other business organization in capitalist society $[12,13-15]$.

The thrust of this argument is the idea that the product or the content of the media may be shaped by corporate interests, basically, the interest of the owners $[13,16]$. Therefore, the media is thus obliged to meet the needs of owners, the audiences; advertisers as well as media employees by employing a delicate balance between these stakeholders which, therefore, influence the media content $[12,17,18]$.

However, all approaches to the political economy of media take it as axiomatic that the media industries, the structure of the markets they operate in, their patterns of ownership, the strategies of key players, and the trajectory of development, and so on are important objects of analysis [19]. It is, therefore, necessary to know in what kind of an economic environment the media exist, it be the internet, television, and print. It is also pertinent to understand how the media produces news, information, ideas, and entertainment and by whom it is controlled since the formulation and implementation of the policies that make the media all have cultural, social, political and economic consequences [20].

\section{New Media}

Influence of the Media Industry, Culture Industry and Political Economy of the media.

Moscov [21] remarked that the political economy of the media of communication is "the study of the relations, particularly the power relations that mutually constitute the production, distribution, and consumption of resources". These resources at this vantage point are the products of communication, such as newspapers, books, videos, films. This implies that the political economy of the media deals with how media information is generated distributed and consumed within a society and the power that influences these media information generation and distribution. argue that "economic factors/ market forces impact on the media in ways in which it becomes an industry". The media, therefore, operate as an economic institution in the business of cultural production. Journalists, web creators, blog creators etc come up with information that will encourage readership and therefore sell it to the readers. In a sense, media owners are in a position to control the kind of information that will appeal to their readers' interests and at the same time not offend advertisers.

Therefore, the media industry through their programmes captures our attention and makes us glue to such progarmmes. As such, audiences frequently watch such programmes thereby making the programme to be popular and increasing the chances of advertisers to use such programmes as a medium which prompts for buying and selling via advertisement. Furthermore, in analyzing the content of the media, Ogenga [12] affirmed that the product or the content of the media may be shaped by corporate interests, basically, the interest of the owners as well as the ruling class. Therefore, the new media is not an exception, sources (bloggers), internet content creators, as well as producers of information on the internet put up things online to protect certain interests or ideology. This implies that no matter how free of access to information is in the new media, cultural industry, capitalism, as well as other ideology and restriction to access of information that requires payment affects it. That is when very important and vital information is placed on the internet, the originator of such information would require you pay money to access such information. Buttressing on this remark that "modern day criticism has forced students and teachers to see that there are no innocent texts (messages), that all artifacts of the established culture and society are laden with meaning, values, biases, and messages that advance relations of power and subordination, and there is no pure entertainment that does not contain representations, often extremely prejudicial, of class, gender, race, sexuality, and myriad social categories and groupings. Cultural texts are saturated with social meanings, they generate political effects, reproducing or opposing governing social institutions and relations of domination and subordination".

This implies that every message or information uploaded on the internet is influenced and driven by a force, either capitalism or individual biases or understanding. Therefore, the culture industry aided by the media industry in a political capitalist society dish out industrialized culture through the internet and other mass media at large and the consumers yearn for more and more of the culture making it both popular and mass, thereby embracing it without a second thought. For instance, youths' today are always after the latest handsets in town because of its update in functionality. In like manner, they want to buy the latest iPhones and other gadgets; all these technologies are the product of the media industry (supported by capitalist and capitalism) made available to the people. Agreeing to this, Price-Mitchell (ND) captures the influence of new media today, He avers that "honestly, I sometimes truly wish that 'tools' such as the iPhone (or any smartphone), laptops, iPods, tablets, etc. hadn't been invented. Sure, they're great, incredibly useful, and fun time-killers. But the way teenagers abuse them, and turn them into mini social control rooms is frankly awful." This implies that the new media and other new technologies show that we are only consumers and little producers. In addition, remarks that the power of the message of media today is held by the message makers, the privileged few, while the masses are powerless message receivers who have no choice but to be exposed to the manipulation. The media confuses reality and art, which cause among the masses a decline of their sensibility to reality and an increase of their illusions and then get trapped thereby losing their ability of free thinking. All we do is to consume and want more of what technology can provide. Supporting this notion, Kellner [4] avers that the media dominate many people's leisure activities and help construct how people see the world and insert themselves in the established society. This is true because people today glue themselves to TV programmes, vote for celebrities on TV soap operas, and download millions of information from the internet without considering its authenticity. They also buy new Jean Trousers and other clothes advertised in the media, as well as chat day and night without questioning the credibility of media sources. For instance, the Big Brother Nigeria Show held at South Africa made millions of Naira through a (Mobile SMS) of people who voted. This shows that the consumers have suddenly become part of those promoting capitalism making the rich richer.

As postulated by Horkheimer and Adorno industrialized produced culture takes away people's imagination and thinking as well. The culture industry distributes commodities in such a way that people are left over with the task of the consuming them. This implies that people today are left with only consuming what the culture industry offers them through the media industry which is supported and financed by the capitalist. 
On the other hand, examining the restriction of media and its content as regards to the political economy of the media. Djankov et al. [22] affirm that in media regulations and ownership throughout the world, governments regulate media using measures ranging from content restrictions in broadcasting/website licenses to constitutional freedom of expression provisions. The types of regulations and their enforcement vary significantly within our sample countries. This implies that no matter how free the new media is, there are still certain limitation to its contents access, which could be either content or proxy/server access restriction. A good example is a restriction on the use of Facebook through WIFI by staff and students at the European University of Lefke, North Cyprus within the campus environment, students are only allowed to Facebook using wireless during weekends. This, therefore, shows that there is a limitation to the access of information in the new media. Albeit to the access of information in new media, the content of new media itself is sometimes not reliable. In accordance with this, Askoul [23], affirmed that "new media is not always a reliable source to get news from because anyone can post wrong news just for fun and grab attention. There is no publisher to check whether the information was written is wrong or right, unlike newspaper, TV, or radio where there is always an editor and publisher that ensures that information published to the audience is right". In contrary, one could ask if the media and cultural industries are doomed to be short-circuited by user-created content and usergenerated prescriptions. Commenting on this, Leonhard [24], avers that "in a drastic departure from the good old one-way, top-down, Media-obsessed 'culture' of the past, we are now witnessing a seemingly ubiquitous trend to media forms that allow, or better yet, promote participation, self-expression, and user engagement and the media and so-called 'content' industries are the first to feel it." As far as Leonhard is concerned, the two-way communication process that the new media presents have crippled the autonomy of the media, He rejects the notion that we are passive consumers but rather see us as an active participant that can choose the form of communication that influences us. As far as this scholar is concerned, the political economy, culture industry, and the media industry are less powerful today due to the pluralisation of communication. Buttressing on this, Tsegyu [25], avers that the shift from the hypodermic needle assumption of one-way communication to a more dynamic two-way communication has been made possible with the advent of information communication technology which has placed the power of the media in the hands of the ordinary citizens today. Therefore, the Internet has eroded the "privileged position of the media to interpose itself between source and user." Supporting this claim Jenkins [26], remark that users have risen from the ghetto to the centre stage of the media arena and of cultural production; the more they contribute to content creation, the more this will enhance both cultural diversity and economic growth and that participatory culture is resolving the historical antagonism between "community" and "commodity" a profound change of paradigm, in which "new media" (the horizontally designed Web-based communities) are systematically opposed to "old media" (the large vertically orientated institutions and corporations of the 20th century).

However, empirical research indicates that dominant trends are far less clear-cut than suggested in these radical visions. From the inception of industrialization, information and culture have always received relative success of circulation through consumers of the media. I.e., industrialized culture has been made so possible through the exchange of information from one consumer to the other [27]. Thus, in so many cases, the old media industries have benefitted from the digital media inception, and now leverage significant revenue from user-generated content. This implies that there are new forms of collaboration between content generating users and industrial players of various sizes, rather than the full-blown conflict. This gives rise to an overall promotion of media products now than ever in the history of industrialized culture and information because the active participation of users is a vital condition for the development of media and cultural industries. This means the more people participate in the exchange of information in the new media the more the culture industry is promoted. One way or the other, consumers keep generating and distributing cultural content that makes capitalism to be stronger. That is, those at the helms of power keep producing cultural contents through adverts, films, opera's etc and we the consumers are unknowingly promoting capitalism. Therefore, in analysing the production of new media information. Mansell [28] avers that the consumption of new media in their commodity form means that scarcity has to be created, for instance, the use of copyright, controlling access, the promotion of obsolescence, the creation and sale of audiences, and by favoring some kinds of new media over others. All this boils down to capitalism and the inequality in the distribution of information that exists in the capitalist society. For example, in Nigeria, it is difficult to browse web of science papers due to the restrictions on them (pay before you download" but there are some countries who do not have such kind of restrictions. Therefore, I disagree with the axiom that the new media has brought complete pluralisation, and free access to information, the researcher sees this axiom raised in this study as relative because even with the advent of new media restriction still exists. We now have what is called "Cybercapitalism" where they 'have' are more opportune to information than the have not. For instance, if a person has money to pay for access to information online he gets it while some do not because of money. So the so-called contents of the new media are sometimes bought, all these improves capitalism [27] puts it, there is a condition of scarcity that is being reproduced as a result of various articulations of power. These contribute to the maintenance of deeply rooted inequality in today, so-called "information" or "knowledge" societies. She adds that in the growing field of the internet studies, there is little explicit treatment of power. Sometimes, the internet is portrayed as a new public space of possibility for individual and communities, but other times, as a commercial space for advertisers and new media business. According to the authors $[28,29]$, "the internet is conceived as a medium that is being socially constructed and as a medium where technology architecture itself favors certain social outcomes". And this is the angle at which I look at the diversity and pluralism of the access to information in the media; I see it as a myth. However, many researchers assume that the capitalist society do not influence the social media which is an aspect of the new media discussed above, due to the fact that social media allows people to be both consumers and producers of information, therefore, the political economy of the social media is seen as a mirage since everyone is a manufacturer and a consumer of products. It is, therefore, necessary to explore the political economy of social media and see how capitalism affects it.

\section{The political economy of social media: the capitalist control - myth or reality}

The framework for social media could be either subjective or more objective in approaches [30,31]. The subjective approaches framework deals with the active participant in the production and circulation of social media content. These people organize and control the media themselves, that is why it is referred to as participatory or as citizen media [32-34]. Whereas, the objective approaches dwells on the content of the social media. It is believed that the content of the social media is 
unlike mainstream media that supports the ruling class, but rather the information supports pluralism of two-way communication against the domination and marginalizes situation that exists in the mainstream media [35]. Against this backdrop, below shows an ideal-typical model of alternative media (social media). Series of literature today, agreed that distinguishing characteristics between actors of media i.e., producers of media, consumers of media and audiences and the structure of media which consist of ownership and control. It is clear that the mainstream media produce media contents which are disseminated to the audience who gives feedback in different dimensions and such feedback is used as clues for further media production $[30,36]$. Therefore, in the mainstream media, the media content is generated and sold to the audience and such information mostly does not question the capitalist spheres but rather applaud capitalism and exploitation [37-39]. That is why in the mainstream media, there exists a dichotomy between the producers and consumers of media, unlike the alternative media (social media) where consumers are also producers and separation between producers and consumers do not exist $[30,31,36]$. Since the critical political economy of the media and communication is an approach that studies the production, circulation, and consumption of information in the context of capitalism, power structures, domination and inequality [21]. I strongly believe that capitalism exists in the new media, for instance, to reach the broader public requires money, people, reputation and political influence, since capitalism is a society grounded in the asymmetric distribution of political, economic and cultural resources and most social media producers and consumers are on a voluntary work, they therefore lack money, attention, influence and other resources which leave them with no choice than to adopt the predominant mechanisms of power, such as advertising, intellectual property rights, for-profit sales, association in order to mobilise resources and to avoid remaining marginal since their organisations tend to be based on unpaid and voluntary work of people who in addition to media activism must earn a living in the capitalist economy, which threatens the stability and existence of alternative media (social media). As puts it alternative media exist against and cannot truly exist within capitalism. They, therefore, face a fundamental antagonism between critical autonomy and voice. Buttressing on this, Atton and Hamilton [40] avers that, the general political-economic dilemma for any critical project is that it needs resources with which to work, but those crucial resources are present only in the very society that it seeks to change or dissolve. Supporting this notion, Jin [41] analyzed the political economy of the most frequently used web platforms and found that 98 percent are for-profit and only 2 percent are nonprofit; 88 percent use targeted advertising as capital accumulation model and 10 percent other models such as the sale of products and services, subscriptions/pay-preview, and classified ads. Therefore, the capitalist domination and control of the internet is very massive. This implies that as we keep producing information on the World Wide Web our data are captured and adverts are devised to suit us. For instance, when you open your mail you see different target adverts to you, it is also seen on Facebook, etc. all these devices are used by the new media to promote capitalism and one way or the other are assisting in the promotion of capitalism. Buttressing on this, Jin [41], remark that "most non-America platforms also use the targeted advertising model that has resulted in major concerns about users' privacy, the exploitation of digital labor and the commercialization of life". That is, the social and new media allows us to fill in our data's such as name, occupation, etc and then design a targeted advert by selling our data's to advertising companies. This means that all information online is one way or the other is tracked by the capitalist, we are only producers of information for the capitalist because the capitalist made the social and new media available and we are just mere producers to benefit the capitalist society. And more so, the restriction of access to some information that requires us to pay money on the internet, shows that the access to information is not totally free neither is it a democratic one which is supposed to be an information of the people for the people and by the people but rather it is information sometimes for those who have the means (income). By paying for access to some information on the internet, capitalism is bound to continue.

\section{Conclusion}

The study has established that the political economy of the media deals with the power relations, that mutually constitute the production, distribution, and consumption of resources and these resources are the products of communication, such as newspapers, books, videos, films, social media, the internet etc.

The study also established that through the media industry, mass culture's distribution is achieved and as people keep watching and using technological devices they are hypnotized into mass culture unknowingly. The culture industry has taken the people's view of reality, totally shaping and conditioning their experience of life and the manner in which the media operate is shaped by their owners, the market environment, and the financial support (from the capitalist). Therefore, the advent of new media has made information to be readily accessible, but such information is affected or influenced by capitalist and capitalism. One needs to ask who produces the information in the new media, who controls it and who distributes and consumes it. The major production of information on the new media is by the capitalist ethos, the adverts, the e-mail, the yahoo, the Google are all produced through capitalism and for profit making. There is an adage that says "even in Freetown nothing is free." The media industry with the help of the capitalist society packages culture and distributes it to the receiving audience who are sometimes influenced to buy them. For example, the Digital Satellite Television (DSTV) in Africa is highly monopolistic and capitalistic that it requires a subscription to gain access to its complete channels. What the new media provides is a tip of information so that we could long for more information and longing for more information requires paying. Therefore, this study debunks the axiom that there is pluralization and democratic access to information because there are lots of information on the internet that are not easily retrieved; they require one to pay for them. For instance, when doing research, a web of scientific papers such as Elsevier, Springer, etc are not open access papers they require a subscription in order to access them. This implies that information in the new media is not democratic nor is it pluralized (not everyone gets access to it). Although, information could be universal and readily available, but its access is restricted from country to country. For instance, in Turkey and North Cyprus one cannot watch pornographic sites this shows there is a limitation of the access to information. Other examples are the secret files of the United States which cannot be accessed without permission even though it is on the World Wide Web.

Going by what democratization is; which is something about the people, for the people and by the people, it could be deduced that the access and production of information on the internet supposed to be something made by the people, for the people and of the people, produced and controlled by the people. Thus, pluralism which deals with everyone having access to something at any given time is not obtainable in the new media. The new media information is available, but accessing such information is limited and keyed. The capitalist society uses the new media for profit making, we pay for "data" 
Citation: Apuke OD (2017) Another Look at the Political Economy of the Mainstream and New Media: The Capitalists Influence. J Mass Communicat Journalism 7: 341. doi: 10.4172/2165-7912.1000341

Page 7 of 7

"WIFI" in order to get access to the information in the new media, why then will one assume that in the world today the diversity of new communication technologies and new media, the democratization of communication, and the universal access to technological content is very possible. Debunking this assertion, this study postulates that it is true that there are new communication technologies, new media, but the communication/information is never democratized neither is there universal access to technological content because the capitalist created the new media and they do so in order to promote cultural industry and to gain profit and the only way to do so is by putting restrictions on information as well as turning the new media into an advertising medium or podium that generates money. As you pay for some classified information online you are promoting capitalism. Therefore, the access to information is not universal it ranges from one geographical location to another base on the type of capitalism that exists in a given geographical location (State, Country or Nation). Thus, the researcher summarized the standpoint of this study below:

\section{References}

1. Apuke OD (2016) Information Communication Technology and Citizen Journalism in Nigeria: Pros and Cons.11: 1-4.

2. Folarin B (1998) Theories of mass communication: An introductory text. Lagos: Stirling-Horden Publishers (Nig) Ltd

3. Okunna CS (2002) Teaching Mass Communication: A Multi-Dimensional Approach. New Generation Books, Enugu. Scientific Research An Academic Publisher

4. Kellner D (2009) Media industries and media/cultural studies: an articulation. Political Economy and Cultural Studies 1-47.

5. Storey J (2015) Cultural theory and popular culture: An introduction, (7th edn).

6. Horkheimer M, Adorno TW, Noeri G (2002) Dialectic of enlightenment. Stanford University Press

7. Kellner D (2002) The Frankfurt School and British cultural studies: The missed articulation. Rethinking the Frankfurt School: Alternative legacies of cultural critique $31-58$

8. Fisher S (2013) Adorno and Horkheimer - "Culture Industry: Enlightenment as Mass Deception" - summary. The cultural reader: article summarizes and reviews in cultural studies.

9. O'Connor J (2010) The Cultural and Creative Industries: A Literature Review, (2nd edn.), Newcastle: Creativity, Culture and Education.

10. Curran J (2000) Rethinking media and democracy'. In: Curran J, Gurevitch M editors. Mass media and society. London: Arnold 120-152.

11. Chomsky N (2003) Undersatnding power: the indispensable Chomsky.

12. Ogenga $F(2010)$ Political economy of the Kenyan media-towards a culture of active citizen journalism. Global Media Journal-African Edition 4: 151-162.

13. Williams K (2003) Understanding media theory. Bloomsbury Academic

14. Mosco $\vee(1996)$ The political economy of communication. Rethinking and renewal.

15. Hesmondhalgh D (2007) The cultural industries. ( $3^{\text {rd }}$ edn.), SAGE publishing

16. Ramaphosa C (1999) The Media, the editors and the owners in Financial Times 14-05-1999: 20-21.

17. Gandy OH (1997) The political economy of the media Volume 1.UK: Edward Elgar Publishing Limited 87-106.

18. Picard RG (1989) Media economics: concepts and issues. Sage publications

19. Winseck D (2011) The political economies of media: The transformation of the global media industries.
20. Ceren S (2011) The political economy of the media in Turkey: A sectoral analysis. TESEV Publications

21. Mosco V (2009) The Political Economy of Communication (2nd edn.), London Sage

22. Djankov S, McLiesh C, Nenova T, Shleifer A (2003) Who owns the media? The Journal of Law and Economics 46: 341-382.

23. Askoul A (2014) Advantages and Disadvantages of New Media.

24. Leonhard G (2008) Music 2.0.

25. Tsegyu S (2016) Citizen Journalism and election monitoring in Nigeria. Journa of Communication 32: 491-517.

26. Jenkins H (2006) Convergence Culture: Where Old and New Media Collide. NYU Press

27. http://www.editions-harmattan.fr/index.asp?navig=catalogue\&obj=livre \&no=24750

28. Mansell R (2004) Political economy, power and new media. New Media and Society 6: 74-83.

29. Castells M (2001) The Internet Galaxy: Reflections on the Internet, Business, and Society. Digital library

30. Sandoval M, Fuchs C (2010) Towards a critical theory of alternative media 27: 141-150.

31. Fuchs C (2010) Alternative media as critical media. European Journal of Social Theory 13: 173-192.

32. Rodríguez C (2001) Fissures in the Mediascape: An International Study of Citizens' Media. Hampton Press

33. Atton C (2002) Alternative Media. SAGE Knowledge

34. Carpentier N (2011) Media and Participation: A Site of Ideological-democratic Struggle. Intellect Books

35. Negt O, Kluge A (1993) Public Sphere and Experience: Towards an Analysis of the Bourgeois and Proletarian Public Sphere.

36. Sandoval M (2009) A critical contribution to the foundations of alternative media studies. Kurgu: Online International Journal of Communication Studies

37. Fuchs C (2011) Foundations of Critical Media and Information Studies. New York: Routledge.

38. Golding P, Murdock G (1997) The Political Economy of the Media. The International Library of Studies in Media and Culture series, Edward Elgar PUBLISHING

39. Wasko J, Murdock HG, Sousa H (2011) The Handbook of the Political Economy of Communications.

40. Atton C, Hamilton J (2008) Alternative Journalism. London: Sage.

41. Jin DY (2013) The construction of platform imperialism in the globalization era. Triple C: Communication, Capitalism and Critique. Open Access Journal For a Global Sustainable Information Society 11: 145-172. 